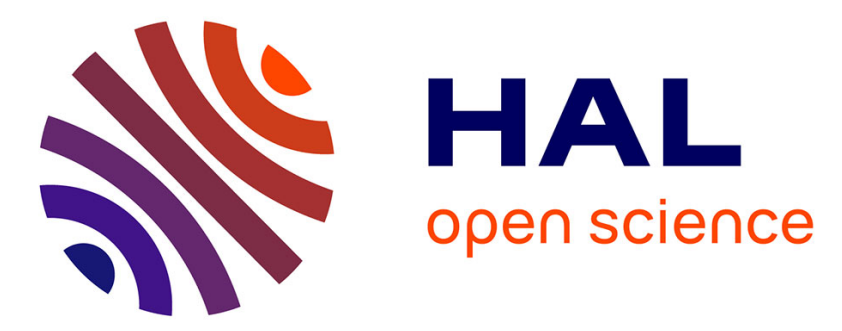

\title{
Thermally assisted mechanical dewatering (TAMD) of suspensions of fine particles: Analysis of the influence of the operating conditions using the response surface methodology
}

Akrama Mahmoud, Aurora Fernandez, Toma Mihai Chitu, Patricia Arlabosse

\section{To cite this version:}

Akrama Mahmoud, Aurora Fernandez, Toma Mihai Chitu, Patricia Arlabosse. Thermally assisted mechanical dewatering (TAMD) of suspensions of fine particles: Analysis of the influence of the operating conditions using the response surface methodology. Chemosphere, 2008, 72 (11), p.17651773. 10.1016/j.chemosphere.2008.04.075 . hal-01643401

\author{
HAL Id: hal-01643401 \\ https://hal.science/hal-01643401
}

Submitted on 19 Dec 2017

HAL is a multi-disciplinary open access archive for the deposit and dissemination of scientific research documents, whether they are published or not. The documents may come from teaching and research institutions in France or abroad, or from public or private research centers.
L'archive ouverte pluridisciplinaire HAL, est destinée au dépôt et à la diffusion de documents scientifiques de niveau recherche, publiés ou non, émanant des établissements d'enseignement et de recherche français ou étrangers, des laboratoires publics ou privés. 


\title{
Thermally assisted mechanical dewatering (TAMD) of suspensions of fine particles: Analysis of the influence of the operating conditions using the response surface methodology
}

\author{
Akrama Mahmoud $^{\mathrm{a}}$, Aurora Fernandez ${ }^{\mathrm{b}, *}$, Toma-Mihai Chituchi ${ }^{\mathrm{a}}$, Patricia Arlabosse ${ }^{\mathrm{a}}$ \\ ${ }^{a}$ RAPSODEE CENTRE (UMR CNRS 2392), Ecole des Mines d'Albi-Carmaux, Campus Jarlard, 81013 Albi CT Cedex 09, France \\ ${ }^{\mathrm{b}}$ INSA Toulouse UMR5504, UMR792 Ingénierie des Systèmes Biologiques et des Procédés, CNRS, INRA, INSA, F-31400 Toulouse, France
}

\begin{abstract}
A B S T R A C T
Thermally assisted mechanical dewatering (TAMD) is a new process for energy efficient liquid/solids sep aration which enhances conventional device efficiency. The main idea of this process is to supply a flow of heat in mechanical dewatering processes to favour the reduction of the liquid content. This is not a new idea but the proposed combination, especially the chosen operating conditions (temperature $<100{ }^{\circ} \mathrm{C}$ and pressure $<3000 \mathrm{kPa}$ ) constitutes an original approach and a significant energy saving since the liquid is kept in liquid state. Response surface methodology was used to evaluate the effects of the processing parameters of TAMD on the final dry solids content, which is a fundamental dewatering parameter and an excellent indicator of the extent of TAMD. In this study, a two factor central composite rotatable design was used to establish the optimum conditions for the TAMD of suspensions of fine par ticles. Significant regression models, describing changes on final dry solids content with respect to inde pendent variables, were established with regression coefficients (usually called determination coefficients), $R^{2}$, greater than $80 \%$. Experiments were carried out on a laboratory filtration/compression cell, firstly on different compressible materials: synthetic mineral suspensions such as talc and synthetic organic suspensions such as cellulose, and then on industrial materials, such as bentonite sludge provided by Soletanche Bachy Company. Experiment showed that the extent of TAMD for a given material is par ticularly dependent on their physical and chemical properties but also on processing parameters.
\end{abstract}

\section{Introduction}

Mechanical dewatering via filtration and compression, com pared to thermal processes, is widely used in different fields (chemical and pharmaceutical industry, wastewater treatment,...) due to its low energy requirement (Mihoubi et al., 2003; Vaxelaire and Olivier, 2006). However, for many applications, it cannot en sure sufficiently low water content. Therefore some current re search tends to propose potential alternatives to enhance the dewatering ability of conventional processes (Mahmood et al., 1998; Strauss, 1998; Peuker and Stahl, 2001; Couturier, 2002; Fer nandez et al., 2005).

Intensification of dewatering processes results in the combina tion of mechanical and thermal effects (pressure and temperature). Coupling of these can be envisaged during the filtration regime only, the compression regime only, during both regimes or as a pre or post treatment of the dewatering stage. Various processes were experimented at lab and pilot scales but, most of the time, the operating conditions lead to a vaporization of the solvent.

\footnotetext{
* Corresponding author. Tel.: +33 (0) 561559750; fax: +33 (0) 561559760

E-mail address: Maria-Aurora.Fernandez@insa-toulouse.fr (A. Fernandez).
}

The thermally assisted mechanical dewatering process is espe cially suited for the dewatering of materials insufficiently treated by conventional methods for the reduction of water content. A wide field of application is colloidal systems in which dewatering is complicated because of the strong surface effects. Due to the high bonding forces of water to solid matter and strong electro static forces between small particles, strong mechanical forces have to be applied at room temperature for purely mechanical dewatering (Bergins et al., 1998, 1999a,b; Wakeman and Tarleton, 1998). Other applications of the combined technique are fine par ticle suspensions $(<20 \mu \mathrm{m})$, which can barely be filtered. Although the molecular interactions play a far smaller role, they still domi nate the kinetics of the reduction of the water content. This water content can be as high as $95 \%$ on a wet basis (wt\%). The amount of water that can be removed depends on the mechanical dewatering process and the status of the water in the materials. Various inter pretations of the types of water found in fine particle suspensions are offered (Bouyoucos, 1921; Vesilind, 1979; Smollen, 1990; Tsang and Vesilind, 1990; Vesilind and Martel, 1990; Robinson and Knocke, 1992). Although these categorizations differ in nomenclature, they all take the following forms: (a) free water that is not attached to the particles and can be removed by gravitational 
settling; (b) interstitial water that is trapped within the flocs or ex ists in capillaries of the dewatered cake and can be removed by strong mechanical forces; (c) surface water that is held on the sur face of the solid particles by adsorption and adhesion; and (d) intercellular and chemically bound water. The water that can be removed relatively easily using mechanical dewatering is usually known as "free water" and the remaining as "bound water". The free water so defined includes the truly free, interstitial, and some of the surface water. The bound water, which is the theoretical lim it of mechanical dewatering (Vesilind, 1994), includes the chemi cally bound water and the remainder of the surface water.

The operating conditions of temperature and pressure used in the thermally assisted mechanical dewatering (TAMD) are suffi cient to remove a significant proportion of the water that cannot be removed using mechanical dewatering technologies. The TAMD thus has the potential to be viable for a range of materials, for which strict conditions are required to achieve significant dewatering.

In this study, for economic reasons (for mechanical dewatering, the separation cost ranges between 1 and $50 \mathrm{kWhm}{ }^{3}$ of solvent eliminated against $7501150 \mathrm{kWhm}{ }^{3}$ for thermal drying), operat ing conditions of temperature and pressure were moderate when compared with the usually applied in this kind of processes. These conditions guarantees that water will remain in the liquid phase, as in the mechanical thermal expression process studied in the Universities of Dortmund (Bergins et al., 1999a, 2007; Bergins, 2003, 2004) and Monash (Clayton et al., 2006, 2007).

Many experimental factors can influence the reduction of water content and, consequently, the process yield. The critical process ing factors are temperature, pressure, time, particle size and $\mathrm{pH}$. A study of the influence of certain of these factors should indicate the optimum experimental conditions. Treating each factor sepa rately would be very time consuming; furthermore, if several fac tors play a role, their interactions would not be discernable even if they were dominant. Hence, the use of an experimental factorial design and of the response surface methodology (RSM), already successfully applied in other fields, is well suited to the study of the main and interaction effects of the factors on the dewatering yield.

A central composite rotatable design (CCRD) is one of the most useful approaches in determining optimum conditions of many processes (Cochran and Cox, 1957; Khuri and Cornell, 1987). It ex plores the response surfaces covered in the experimental design, thus making the optimization process more efficient and effective. RSM is defined as statistical tool that uses quantitative data from appropriate experimental design to determine and simultaneously solve multivariable equations (Giovanni, 1983).

The present paper investigates the effects of the processing temperature and pressure of the TAMD at moderate process condi tions, for the reduction of water content in different materials, by using the RSM. Other parameters, such as particle size and pH, as mentioned above, can affect the dewatering behavior, but these are not discussed in this paper. Preliminary tests at laboratory scale on two synthetics suspensions are carried out and inter preted. Then the feasibility of the TAMD on an industrial sample provided by Soletanche Bachy Company is analyzed. Experimental runs are modelled for the estimation of the final dry solids content, allowing the significance of the various phenomena to be dis cussed. Finally, in order to design efficient processes, the RSM is used to achieve the optimum dewatering performance.

\section{Theoretical background}

For the TAMD to be viable on a laboratory/industrial scale, it has to be able of dewatering the given product to the desired water content at a sufficient rate to meet throughput demands. There fore, it is necessary (i) to describe the different dewatering mech anisms involved in the TAMD, (ii) to understand factors that significantly affect the rate of dewatering and the achievable water content and (iii) to illustrate the importance of each dewatering stage in the overall dewatering performance. Looking closer at the mechanism of the TAMD, we briefly specify a theory for the thermal mechanical dewatering steps.

\subsection{Mechanical dewatering steps (filtration compression)}

During the mechanical dewatering process two steps can be distinguished: the so called filtration stage and the compression stage.

In the filtration stage, the compressive piston pushes the slurry in the direction of the filtering media and a filter cake builds up. The filtrate flows through the porous cake and filtering media and the ratio of the pressure drop across the filtering media to the pressure drop across the cake decreases. As the cake builds up, the hydraulic pressure near the filtering media approaches zero and the hydraulic pressure at the top of the cake and in the suspen sion remains constant (La Heij et al., 1996).

The compression stage begins when the compressive piston comes in contact with the filtration cake and the cake is com pressed into a more compact form. The decreasing volume of the cake leads to a minimum amount of water in the pores. The filter ability of this cake and its ability to express the liquid are essential parameters of the separation process. They largely depend on the cakes structure, which is fixed by the operating conditions and the suspension properties (Reichmann and Tomas, 2001).

\subsection{Thermal mechanical dewatering step}

The mechanical dewatering is, in principle, limited by the resis tance of the solid structure against deformation. An essential accel eration of dewatering could be achieved by increasing the temperature (Bergins et al., 1999b). Mechanical and thermal ef fects, resulting in the reduction of water content, are a combination of different mechanisms (Bergins et al., 1998; Artanto and Chaffee, 2005): (i) the mechanical dewatering reduces the volume of the pores and squeezes the water out of the product, (ii) the applica tion of elevated temperatures reduces the liquid density and vis cosity, and the surface tension. The decreased viscosity, density and surface tension lead to the pores structure to hold a smaller mass of water, some of which flows out of the product, and (iii) at high temperatures, the water in a porous vegetable matter is in a mobilized state. This can occur through hydrophobization dur ing the strong decrease in polar groups, through the destruction of cellular structure and more easily overcoming the electrostatic forces of attraction between water and particles (Bergins et al., 1999b).

The investigation of these mechanisms during the TAMD of used materials is not discussed in this paper and requires further and continuing investigations.

Table 1

Properties of the solids and the suspensions

\begin{tabular}{llll}
\hline Variable & Talc & Cellulose & Bentonite \\
\hline Source & VWR International & JRS & Soletanche \\
& S.A.S & PHARMA & Bachy \\
Solid density $\rho_{\mathrm{s}}\left(\mathrm{kg} \mathrm{m}^{3}\right)$ & 2765 & 1552 & 2200 \\
Median diameter $d_{50}(\mu \mathrm{m})$ & 11 & 20 & 16 \\
Dry solids content $S(\%)$ & 40 & 21 & 10 \\
Water content $X$ & 1.5 & 3.75 & 9 \\
$\quad\left(\operatorname{kg}_{\text {water }} \mathrm{kg}_{\text {dry solids }}\right)$ & & & \\
Shape of particles & Sheet & Fibrous & Spherical \\
\hline
\end{tabular}


a
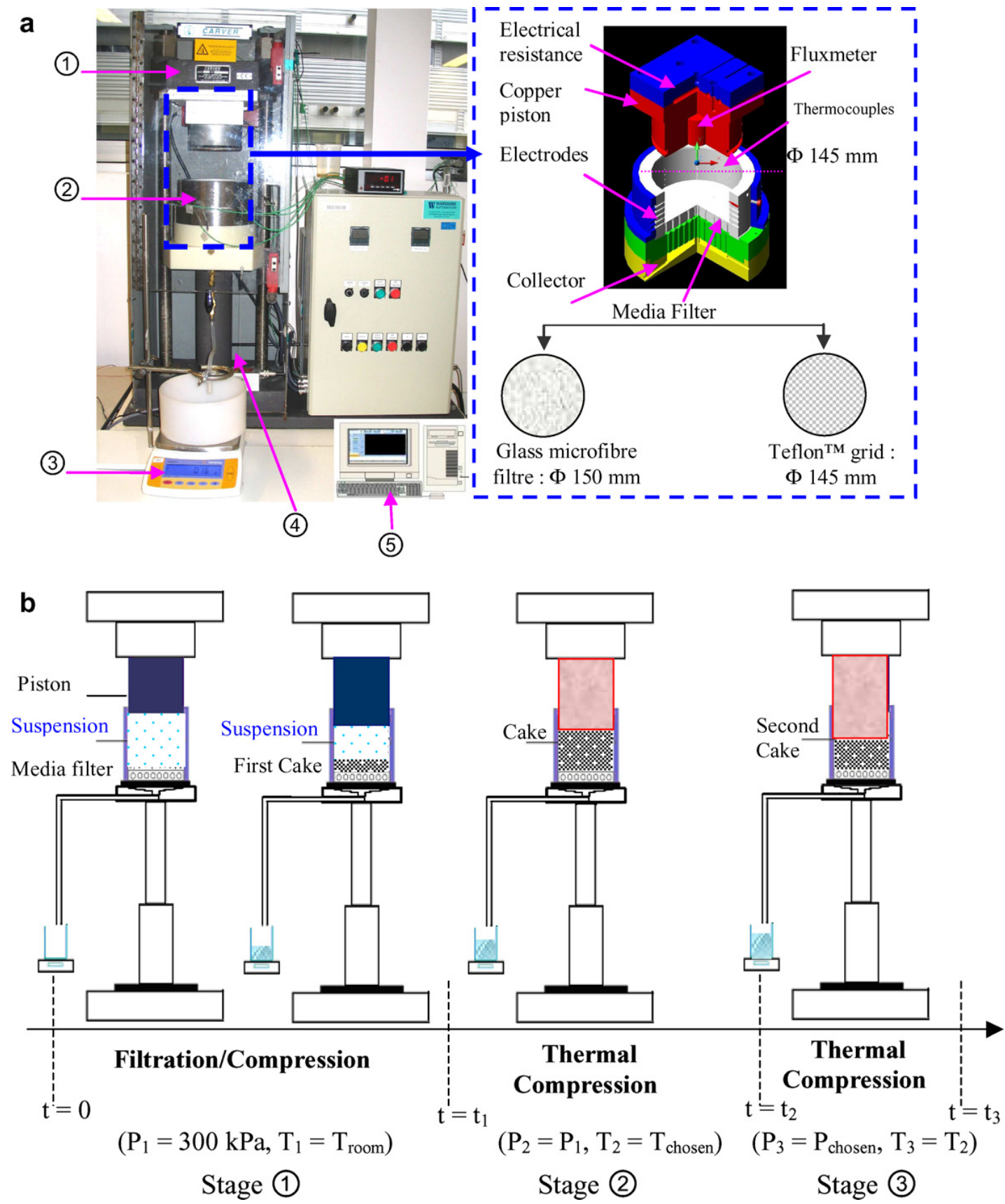

Fig. 1. (a) Laboratory scale of TAMD device: (1) CARVER ${ }^{\circledR}$ hydraulic press; (2) filtration/compression cell; (3) electronic scale; (4) movement sensor; (5) computer and data acquisition. (b) Schematic representation of the different stages of our TAMD.

\section{Materials and methods}

The different materials analyzed in the experiments can be clas sified into synthetic suspension and industrial sludge. The most important physical properties of the solids and the suspensions are measured and reported in Table 1 . These materials are pre sented as follows:

\subsection{Synthetic suspensions}

Two types of synthetic aqueous suspensions, talc and cellulose, were used for this study. These materials were chosen according to the different compressibility of their cakes. Some important phys ical properties of the solids and the synthetic suspensions, includ ing solids density, shape of particle, size distribution, initial water content (dry solids basis) and initial dry solids content, are listed in Table 1. Talc and cellulose were supplied by VWR international and JRS Pharma, respectively. The particle size distribution of these materials was determined using the laser diffraction spectrometry (Malvern Master Sizer MS20).

\subsection{Industrial sludge}

The performance of the TAMD on sodic bentonite sludge, pro vided by Soletanche Bachy Company, was investigated. This min eral material is used in the construction industry, especially as a 
sealing agent, to fix grounds and slopes during work. This clay is a great ability to absorb water and to swell accordingly underwent a treatment to control its rheological properties. At the end of the building, the clay is recovered and re used providing its plastic properties are not corrupted. At the end of the cycle, landfilling is the only acceptable disposal route from the environmental point of view. Since the product contains nearly $90 \%$ water, increasing difficulties are encountered for the admission of this pasty waste to landfill. Furthermore, the elimination cost is strongly penalized by the cost of water transport and storage.

\section{Experimental approach}

\subsection{Experimental set up}

At laboratory scale, the TAMD device, schematically repre sented in Fig. 1a, consists of a filtration/compression cell inserted in a CARVER ${ }^{\circledR}$ hydraulic press, which has a maximum pressing capacity of $14.8 \mathrm{MPa}$. The compressive piston (external diame ter $150 \mathrm{~mm}$ ) is made of copper and is heated by three thermal resistances, which can supply up to $350 \mathrm{~W}$ each.

A Teflon ${ }^{\mathrm{TM}}$ lined cylindrical vessel with a stainless steel external jacket is used to hold the product to be treated. A microfibers glass filter $\left(\right.$ Whatman ${ }^{\circledR}$ ) deposited on a Teflon ${ }^{\mathrm{TM}}$ grid is used as filter media. The filtration/compression cell is specifically instrumented with the following: (i) three thermocouples inserted into the cop per piston; (ii) thermocouples arranged at various heights on the cell wall measure the product temperatures; (iii) a movement sen sor gives the thickness of the cake as a function of time; and (iv) scale measure the mass of solvent separated.

To carry out a dewatering experiment, the product is poured into the cylindrical vessel. The filtrate is collected in a beaker deposited on a scale and data are transferred to an on line computer. The filtrate mass as well as the pressure applied and the piston temperatures are recorded during the experiments on an on line computer. The initial and final water contents of the product are measured according to the AFNOR standard procedure N X31 505 (AFNOR, 1994). They were determined by drying at $105{ }^{\circ} \mathrm{C}$ during $24 \mathrm{~h}$ and weighing. When both sets of data are avail able they can be converted one to the other, and as such serve to check that mass balance is preserved during the experiment. The initial solids content in the suspensions should be ascertained before a test and this can be converted into the corresponding dry solids content in the suspension using:

$S \frac{m_{\mathrm{S}}}{m_{\mathrm{L}}+m_{\mathrm{S}}}$ where $m_{\mathrm{S}}$ and $m_{\mathrm{L}}$ are the mass of dry solids and liquid, respectively. The water content of liquid/solids mixtures can be defined by:

$X \frac{m_{\mathrm{L}}}{m_{\mathrm{S}}}$

\subsection{Experimental protocol}

\subsubsection{Suspension preparation}

For the synthetic suspensions, the first step is the preparation of a saturated suspension with high water content. The saturated synthetic suspension is prepared from talc and cellulose individu ally and deionized water, at room temperature. For the industrial sludge, all the experiments were performed using samples $(800 \mathrm{ml})$ from a sludge tank. After the sampling, the rest of the sludge was stored at $4{ }^{\circ} \mathrm{C}$ until required for testwork.

The TAMD applied in this work, as shown in Fig. 1b, consists of three dewatering stages: (1) filtration/first compression, (2) ther mal first compression and (3) thermal second compression. The three stages are discussed in detail in the following sections.

\subsubsection{Filtration/first compression at room temperature with a pressure} applied of $300 \mathrm{kPa}$ (stage 1)

About $800 \mathrm{ml}$ of the test suspension was poured at room tem perature into the filtration/compression cell. During filling, the ini tial arrangement of the particles in the suspension is not reproducible. Thus, the first stage enables the control the cake for mation and to lower repeatability errors. This stage token place at room temperature with a pressure applied of $300 \mathrm{kPa}$. Conse quently, the pressure regulation of the Carver press must be suffi ciently precise not to induce deviation in the cake structure. The absolute precision on the pressure regulation is $\pm 0.15 \mathrm{kPa}$ around the set point. This step was continued until a cake thickness con stant which means $0.3 \mathrm{~h}$ in the case of synthetic suspensions and $1 \mathrm{~h}$ in the case of bentonite sludge.

\subsubsection{Thermal/first compression cell at the selected operating temperature with a pressure applied of $300 \mathrm{kPa}$ (stage 2)}

Following the cake formation, the hybrid process was applied. The piston was heated at the selected operating temperature, the pressure on the cake being maintained to $300 \mathrm{kPa}$. Three hours were necessary to reach the thermal equilibrium in the filtration cake heated by conduction. A cake, consolidated under $300 \mathrm{kPa}$, was obtained at the end of stage 2 of the protocol. This cake pre sented a temperature profile depending on the selected piston temperature.

Table 2

Observed and predicted responses and determination coefficients for the three studied substances

\begin{tabular}{|c|c|c|c|c|c|c|c|c|}
\hline \multirow[t]{3}{*}{ No. exp. } & \multirow[t]{3}{*}{$T\left({ }^{\circ} \mathrm{C}\right)(\mathrm{X} 1)$} & \multirow[t]{3}{*}{$P(\mathrm{kPa})\left(X_{2}\right)$} & \multicolumn{4}{|c|}{ Synthetic suspensions $S(\%)$} & \multirow{2}{*}{\multicolumn{2}{|c|}{$\begin{array}{l}\text { Industrial sludge } S(\%) \\
\text { Bentonite }\end{array}$}} \\
\hline & & & \multicolumn{2}{|l|}{ Talc } & \multicolumn{2}{|l|}{ Cellulose } & & \\
\hline & & & Observed & Predicted & Observed & Predicted & Observed & Predicted \\
\hline 1 & 21 & 1650 & 68.86 & 69.76 & 54.25 & 54.46 & 30.00 & 24.63 \\
\hline 2 & 31 & 700 & 69.06 & 67.47 & 49.63 & 48.84 & 27.50 & 31.61 \\
\hline 3 & 31 & 2600 & 73.11 & 73.06 & 57.20 & 57.45 & 35.00 & 39.31 \\
\hline 4 & 55.5 & 300 & 66.01 & 67.76 & 45.12 & 46.27 & 53.00 & 51.72 \\
\hline 5 & 55.5 & 1650 & 74.96 & 74.96 & 56.24 & 56.25 & 65.74 & 65.74 \\
\hline 6 & 55.5 & 1650 & 74.96 & 74.96 & 56.24 & 56.25 & 65.74 & 65.74 \\
\hline 7 & 55.5 & 3000 & 76.61 & 76.19 & 59.88 & 59.57 & 67.00 & 65.44 \\
\hline 8 & 80 & 700 & 72.51 & 71.25 & 52.84 & 51.76 & 73.04 & 71.57 \\
\hline 9 & 80 & 2600 & 77.33 & 77.60 & 62.01 & 61.96 & 84.53 & 83.26 \\
\hline 10 & 90 & 1650 & 75.22 & 75.65 & 59.08 & 59.71 & 81.43 & 83.43 \\
\hline \multirow{2}{*}{\multicolumn{3}{|c|}{$\begin{array}{l}R^{2} \\
R^{2} \text { (adjusted) }\end{array}$}} & \multirow{2}{*}{\multicolumn{2}{|c|}{$\begin{array}{l}0.933 \\
0.849\end{array}$}} & \multicolumn{2}{|c|}{0.984} & \multicolumn{2}{|c|}{0.980} \\
\hline & & & & & \multicolumn{2}{|c|}{0.963} & \multicolumn{2}{|c|}{0.952} \\
\hline
\end{tabular}


4.2.4. Thermal/second compression cell (stage 3)

Once the desired temperature and the thermal equilibrium in the filtration cake heated by conduction had been achieved, a sec ond compression stage was applied to the heated cake, for $0.5 \mathrm{~h}$ in the case of synthetic suspensions and for $2 \mathrm{~h}$ in the case of benton ite sludge. After these times, filtrate did not recovery. The influence of the temperature on compression will therefore be evident dur ing this stage if the product is sensitive to temperature.

At the end of the experiment, the dewatered cake was released and weighted. Its dry solids mass was determined by drying at $105^{\circ} \mathrm{C}$ during $24 \mathrm{~h}$ and weighing (AFNOR, 1994). The final dry sol ids content after each experiment was calculated by a mass bal ance and by using Eq. (1). The mass balance assumes that all feed suspension is filtered to form a cake, that is, no feed remains in the filter as suspension.

\subsection{Experimental design methodology}

In this study, a CCRD with a quadratic estimations (Cochran and Cox, 1957; Khuri and Cornell, 1987) was used to point out the rela tionship existing between the response function, final dry solids content $(Y)$, and the process variables, temperature $\left(X_{1}\right)$ and pres sure $\left(X_{2}\right)$. The range of variables for the TAMD conditions were based on the preliminary experiments conducted earlier (David et al., 2002). The independent variables were the temperature, $X_{1}$ $\left(2190^{\circ} \mathrm{C}\right)$, and the pressure $X_{2}(3003000 \mathrm{kPa})$.

This design is constructed based on a $2^{2}$ factorial design, two replicates of the central run and eight star points, allowing each experimental response to be optimized. The experimental condi tions selected by this design are listed in Table 2 . The levels chosen for each of the two parameters are also presented in this table. The dependent variable $(Y)$ was expressed as a function of the indepen dent variables known as the response function. The variance for each factor assessed was partitioned into linear, quadratic and interactive components and were represented using the second or der polynomial function in order to predict each response $(Y)$ in all experimental regions (Box and Draper, 1987):

Y $a_{0}+a_{1} X_{1}+a_{2} X_{2}+a_{12} X_{1} X_{2}+a_{11} X_{1}^{2}+a_{22} X_{2}^{2}$

where $Y$ is the predicted response, $a_{0}$ is the interception coefficient, $a_{1}$ and $a_{2}$ are the linear terms, $a_{12}$ is the interaction term, $a_{11}$ and $a_{22}$ are the quadratic terms, $X_{1}$ and $X_{2}$ represent the coded levels of the process variables (processing temperature and pressure). The rela tion between the coded and natural variables temperature and for pressure, are given as:

$$
\begin{array}{ll}
X_{1} \frac{T T_{\mathrm{c}}}{\Delta T} \\
X_{2} \frac{P \quad P_{\mathrm{c}}}{\Delta P}
\end{array}
$$

where $X_{1}$ and $X_{2}$ are the coded values, $T$ and $P$ are the corresponding natural values. $T_{\mathrm{c}}$ and $P_{\mathrm{c}}$ are the natural values in the centre of the do main: $T_{\mathrm{c}} \quad 55.5^{\circ} \mathrm{C}$ and $P_{\mathrm{c}} \quad 1650 \mathrm{kPa} . \Delta T$ and $\Delta P$ are the increments of $T$ and $P$ corresponding to one unit of $X_{1}$ and $X_{2}$, respectively.

The significance of all terms in the polynomial functions were assessed statistically using the $F$ ratio at probability $(p)$ of 0.05 . The $p$ value tests the statistical significance of the estimated corre lations. $p$ Value below 0.05 indicates statistically significant non zero correlations at the $95 \%$ confidence level. The fitness of the model was evaluated by $R^{2}$, the fraction of the variation explained by the model, and an analysis of variance $F$ ratio. The lack of fit (model error) tests are used to determine whether the selected models are adequate to describe the observed data, or whether an other model should be used (Hastie et al., 2001).

The parameters of the model are estimated from experimental responses by the least squares regression using STATGRAPHICS ${ }^{\circledR}$ software. Following the model fitted for each response, we graph ically represent isoresponses surfaces which are three dimensional of the relationship between the responses and the two factors. This RSM allows experimental response behaviour to be described as precisely as possible as a function of factor variation and optimal conditions of the factors to be determined for each experimental response. The experiments are carried out in a random order according to a central composite design configuration for the two chosen variables.

The model can either be calculated on standardized values or on the experimental values. Both calculations yield useful informa tion: the standardized values allow a mutual comparison of the importance of the different factors with respect to a certain re sponse, whereas the experimental values deliver a predictive model.
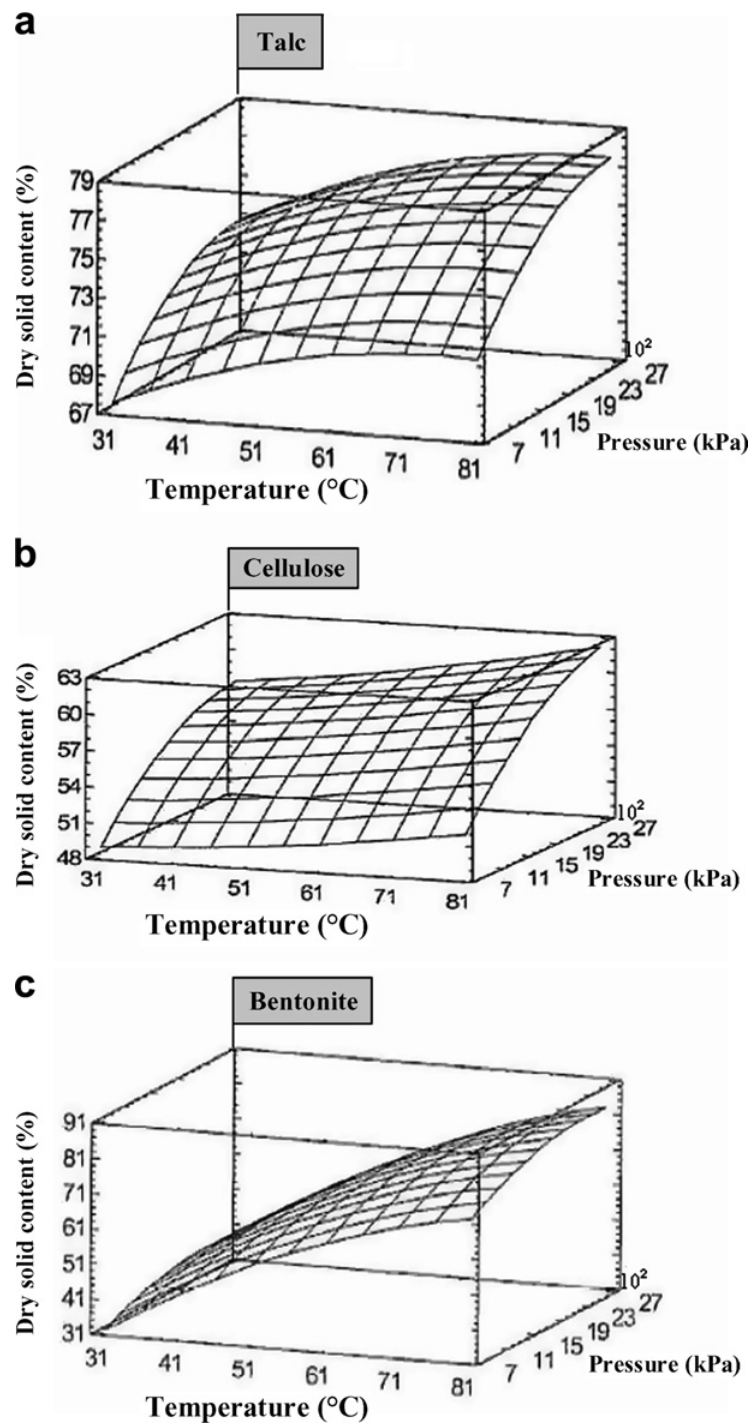

Fig. 2. Estimated response surface for dry solids content of the talc (a), cellulose (b) and bentonite (c) as a simultaneous function of processing pressure and temperature. 


\section{Results and discussion}

5.1. Effect of processing pressure and temperature on the final dry solids content

Ten experiments were required for the RSM. The response sur faces for the dry solids content generated by STATGRAPHICS ${ }^{\circledR}$ soft ware for the experimental design are displayed in Fig. 2. It shows a three dimensional plot for the dry solids content as a function of processing temperature and pressure. From Fig. 2 it can clearly be inferred that these two factors have a profound effect on the dry solids content. It was evident that the dry solids content, $Y$, in creased with the increase in processing temperature $\left(X_{1}\right)$ and pres sure $\left(X_{2}\right)$ during the TAMD. At low levels of $X_{2}$ added processing temperature has little effect on Y.
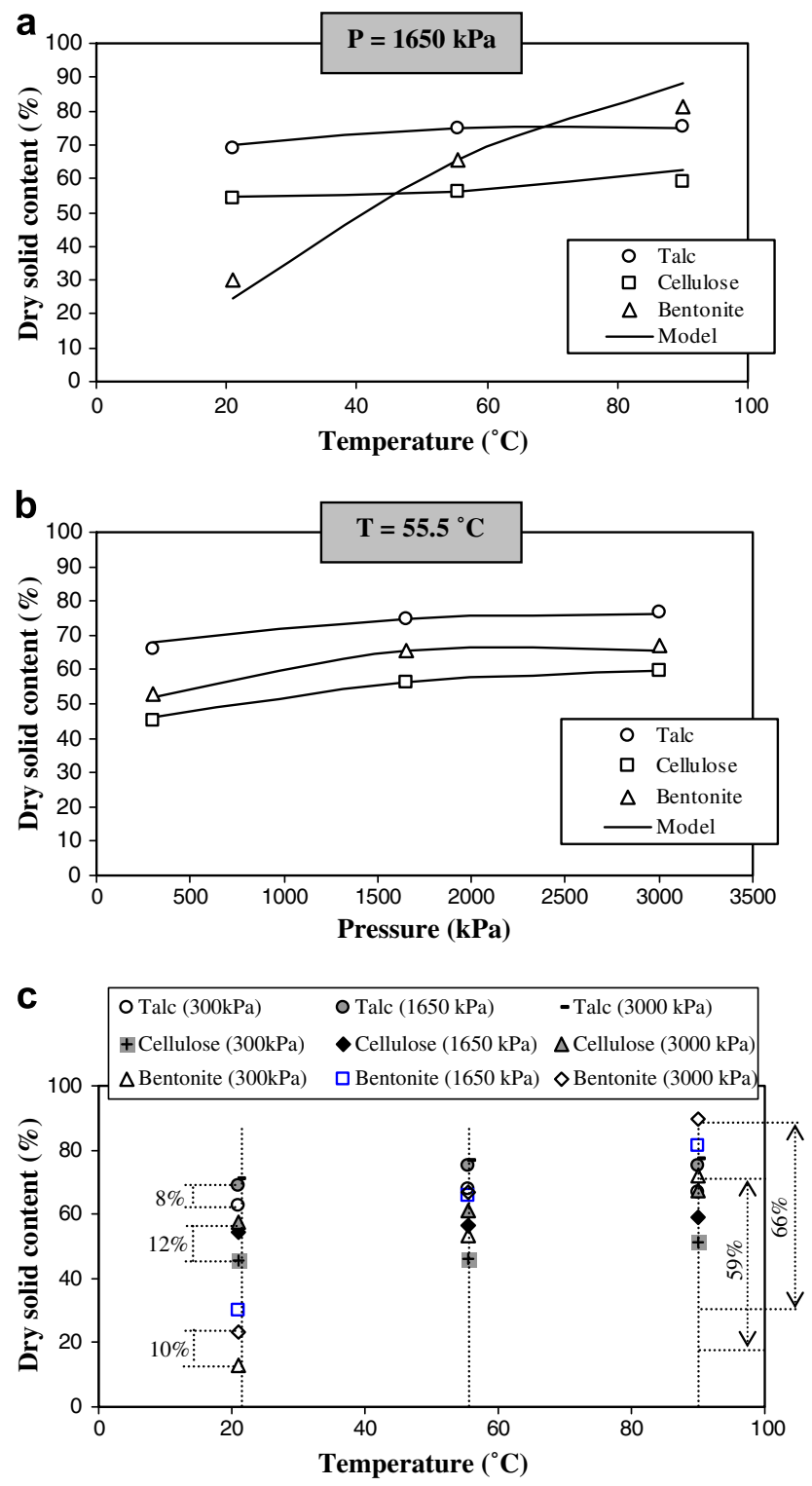

Fig. 3. (a) Dry solids content versus temperature for TAMD testing of used substances at an applied pressure of $1650 \mathrm{kPa}$. (b) Dry solids content versus pressure for TAMD testing of used substances at an applied temperature of $55.5^{\circ} \mathrm{C}$. (c) Dry solids content versus temperature for TAMD testing of three substances at various applied pressures of 300, 1650 and $3000 \mathrm{kPa}$. Experimental data: $(\bigcirc)$ talc, $(\square)$ cellulose, $(\Delta)$ bentonite. Solid lines are predicted values.
As shown in Fig. 2, at low levels of $X_{2}$, the dry solids increase from $67 \%$ to $77 \%$ in case of talc (Fig. 2 a); from $49 \%$ to $65 \%$ in case of cellulose (Fig. 2b) and from $32 \%$ to $87 \%$ in case of bentonite sludge (Fig. 2c) when $X_{1}$ increases from 21 to $90^{\circ} \mathrm{C}$. Similarly, un der the most severe processing conditions $\left(90^{\circ} \mathrm{C}, 3000 \mathrm{kPa}\right)$, the dry solids content of the three studied substances was increased from 40 to $77 \%$; from $21 \%$ to $67 \%$ and from $10 \%$ to $90 \%$, correspond ing to an $37 \%, 46 \%$ and $80 \%$ increasing of the dry solids content originally present in case of talc suspension, cellulose suspension and bentonite sludge.

An indication of the extent of the TAMD that is induced from increasing the processing temperature and pressure can be given by looking at the change in the final dry solids content between (i) three temperatures at a given applied pressure and (ii) three pressures at a given temperature applied.

(i) Pressure fixed at central value $(1650 \mathrm{kPa})$. Fig. 3a presents the results for dry solids content with a processing temper ature from 21 to $90^{\circ} \mathrm{C}$ and a processing pressure fixed at its central value $(1650 \mathrm{kPa})$. As a general observation, for typi cal processing conditions of the TAMD $\left(55.5^{\circ} \mathrm{C}\right.$ and $1650 \mathrm{kPa}$ ), $56 \%$ to $75 \%$ of the inherent dry solids content can be achieved. It is evident that the effects of the temper ature are approximately linear for the two synthetic suspen
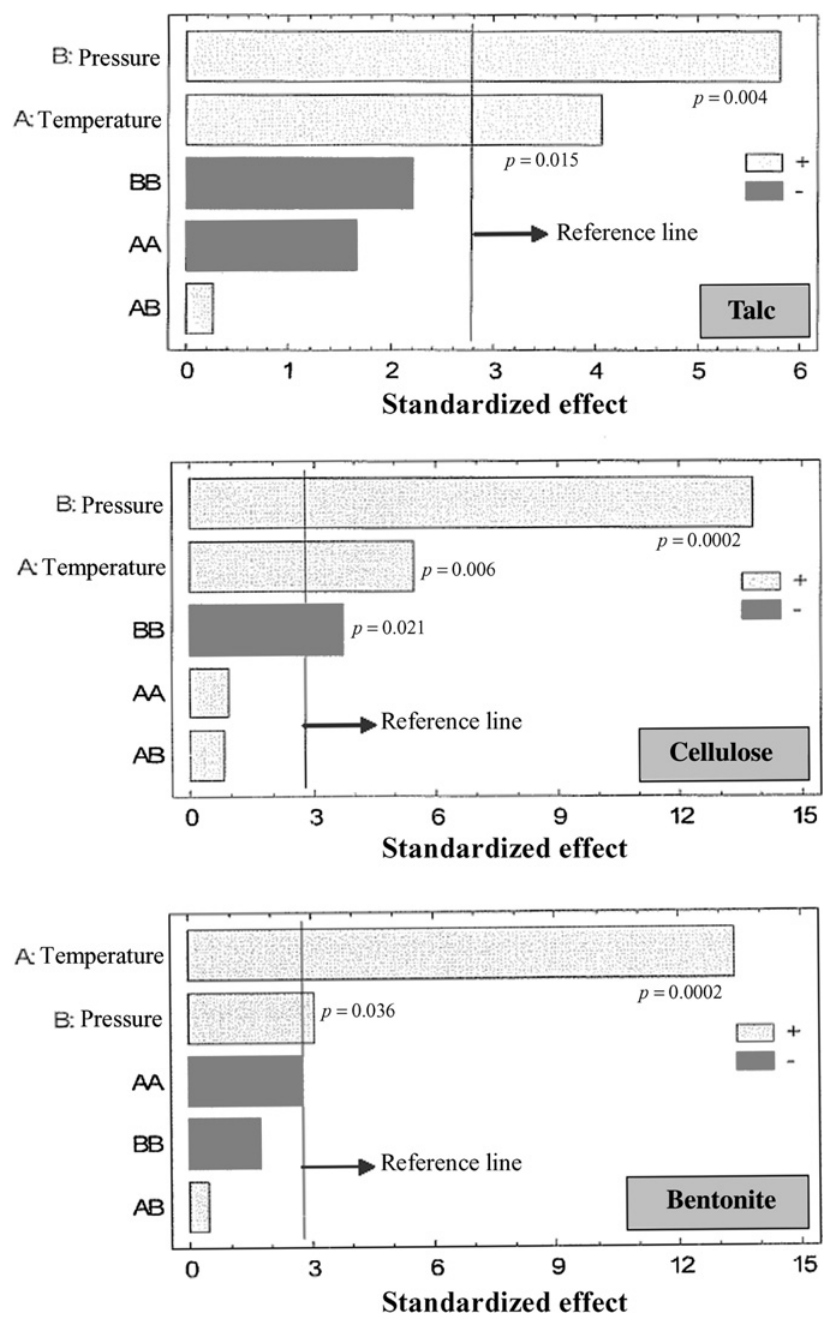

Fig. 4. Standardized pareto chart showing the effects of the independent variables $X_{1}$ (temperature) and $X_{2}$ (pressure) and their combined effects on the dry solids content. 
sions and nonlinear for the bentonite sludge, with an increasing dry solids content for incremental increases in applied temperature.

(ii) Temperature fixed at its central value $\left(55.5^{\circ} \mathrm{C}\right)$.

When the processing temperature is fixed at its central value, $\left(55.5^{\circ} \mathrm{C}\right.$ ), the variation of processing pressure from 300 to $3000 \mathrm{kPa}$ leads to an increase in the dry solids content, as shown in Fig. 3b.

In Fig. 3c, the dry solids content is plotted as a function of tem perature for processing talc, cellulose and bentonite at various ap plied pressures of 300,1650 and $3000 \mathrm{kPa}$.

The results illustrate that at room temperature and with lower applied pressure, a significant proportion of water remains within the studied suspensions after the compression process. For the bentonite sludge, Fig. $3 \mathrm{c}$ shows that after applying the maximum pressure of $3000 \mathrm{kPa}$ and fixing the temperature at room tempera ture, the initial dry solids content increased from 12 to around $23 \%$ (around 10\%). On the other hand, when the processing pressure is fixed at $300 \mathrm{kPa}$, the variation of processing temperature from 21 to $90{ }^{\circ} \mathrm{C}$ leads to an increase in the dry solids content from $12 \%$ to $72 \%$, corresponding to an $62 \%$ increasing of the dry solids con tent originally present. It is clear that increasing the temperature significantly enhances water removal and it is by far the dominant dewatering mechanism.

For talc and cellulose, the predominant parameter is the pro cessing pressure, indicating that these substances are more sensi tive to the mechanical effect, as shown in Fig. 3c. In fact, the variation of processing temperature from 21 to $90^{\circ} \mathrm{C}$, only leads to an increase in the dry solids content of talc substance from $63 \%$ to $67 \%$ (with a processing pressure of $300 \mathrm{kPa}$ ) while for cellu lose, the same variation induced an increase in the dry solids con tent concentration from $45 \%$ to $51 \%$. It can then be assumed that for these substances, most of the water which is removed is present as bulk (free) water around the individual particles (see Section 1). Thus, such water can be removed using relatively low forces.

The model calculation based on the standardized values allows a comparison of the relative influence of the factors on the re sponse, by comparing the square roots of the sum of squares of all the coefficients related to a factor. To determine which factors have a significant impact on the response variable, the Pareto Chart was used (Saveyn et al., 2005). The standardized Pareto Chart con tains a bar for each effect, classed from the most significant to the least significant. The length of each bar is proportional to the stan dardized effect. The length of each bar indicates the effect of these factors and the level of their effects on responses. A vertical line
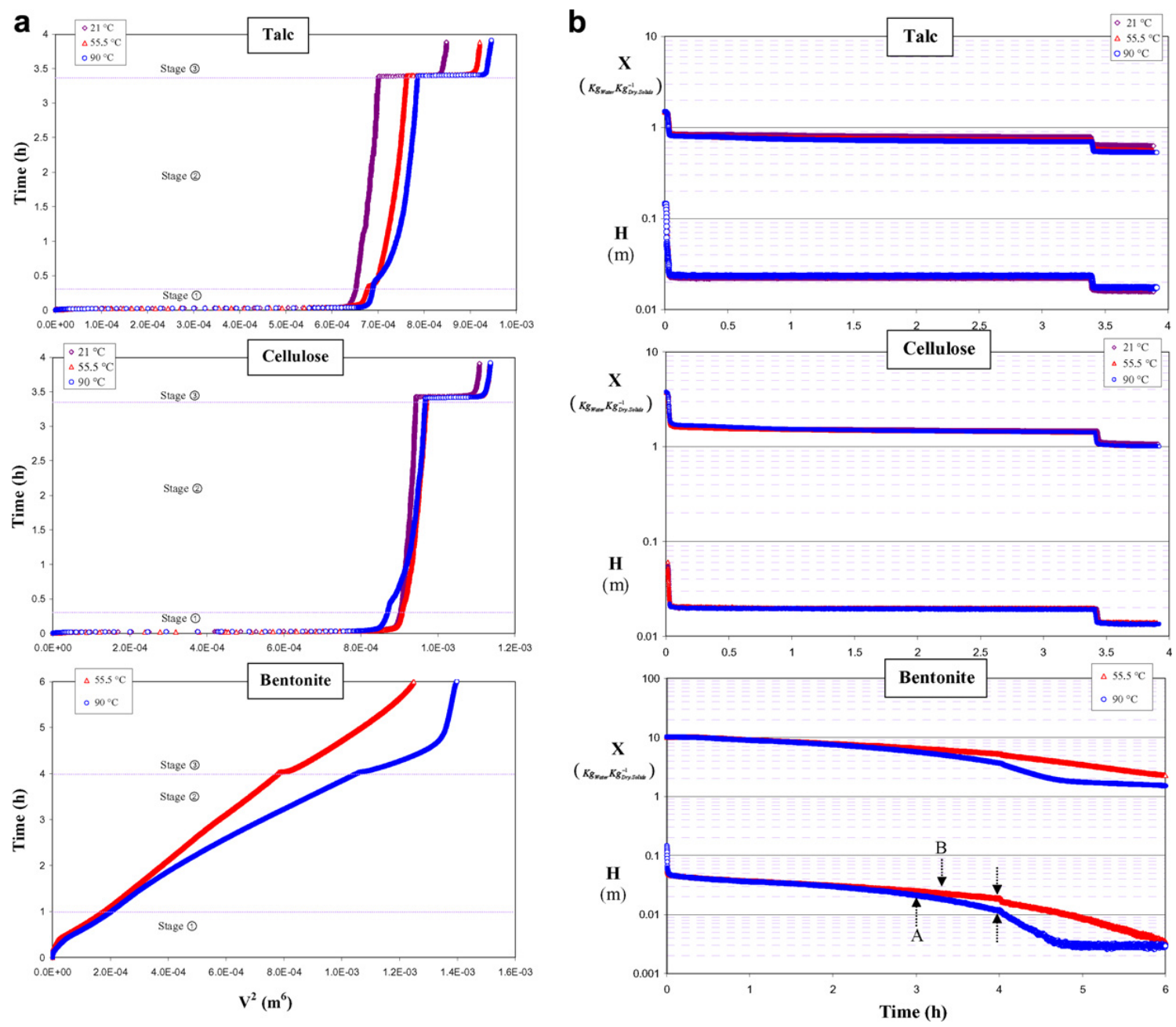

Fig. 5. (a) The overall dewatering curves for TAMD testing of used substances. (b) Water content and cake height versus time, illustrating the three different stages of dewatering involved in TAMD at an applied pressure of $1650 \mathrm{kPa}$ 
(reference line) is drawn at the location of the 0.05 critical value. Any bars that extend to the right of that line indicate effects that are statistically significant at the $5 \%$ significance level. Fig. 4 shows the standardized Pareto Chart and depicts the main effect of the independent variables on the dry solids content.

It can be inferred, as shown in Fig. 4, that the factor B (pressure, $X_{2}$ ), A (temperature, $X_{1}$ ), BB (quadratic effect of pressure, $X_{2}^{2}$ ) in case of cellulose suspension, extending behind the reference line, have a significant effect on the dry solids content. Similarly, there are only two effects with a $p$ value lower than 0.05 for the talc suspension and bentonite sludge, as shown in Fig. 4. However, since the effect involves the interaction of the two main significant effects $\left(X_{1}\right.$ and $X_{2}$ ), a large $X_{1} X_{2}$ interaction is the most likely explanation.

\subsection{Effect of processing pressure and temperature on water content and cake thickness}

The dewatering of a suspension in a filtration/compression cell working under constant pressure is well described by time $t$ versus $V^{2}$ plot. The filtration phase is characterized by the linear part (Fig. 5a). It corresponds to the formation of a cake due to the accumulation of the solid particles on the surface of a filter medium. The second part represents the compression phase. It describes the removal of water by cake squeezing. The ability of the forming cake to let the water go through is commonly characterized, during the filtration phase, by the specific resis tance to filtration. The filtration time, as shown in Fig. 5a, is very long ( $34 \mathrm{~h}$ ) for bentonite sludge, but the amount of filtrate re leased is lower than with synthetic suspensions. This behaviour can be correlated to the mechanisms of flocculation (Saveyn et al., 2005).

The effect of thermal supply on the piston height $(H)$ is shown in Fig. 5b. The starting sample height for all of the experiments is kept at $0.145 \mathrm{~m}$. During the first $3 \mathrm{~h}$, it is the filtration stage in the case of bentonite sludge. At point $A$, the compression stage begins and the reduction of filtrate flow rate allows the heating of the filter cake. The cake thickness decreases slowly until the temperature at the filter medium reaches $90^{\circ} \mathrm{C}$ (point B). Then a fast shrinkage of the cake is observed. The amplitude of the decrease (under the experimental conditions considered) is about $7 \mathrm{~mm}$.

From the viewpoint of the effectiveness of water removal, the water content is a far more meaningful parameter. Therefore, an analysis of the extent of water removal associated with each stage for different processing conditions is required (Clayton et al., 2006). To this end, the percentage of water removal in each stage was determined for a central point at a given applied pressure $(1650 \mathrm{kPa})$. The comparative dewatering performances of the dif ferent TAMD stages are shown in Fig. 5b:

(i) For talc and cellulose suspensions, perusal of all the curve plots indicates that the predominant parameter is the pro cessing pressure. These synthetic suspensions are found to have a higher filtration/compression rate during the first stage $(300 \mathrm{kPa})$ than at later stages. Therefore, most of the water (55\%) was removed during this first stage and there fore, the filtration/compression is the dominant dewatering mechanism. Increasing the temperature (stage 2) removes a relatively small amount of water, even at the highest tem perature of $90^{\circ} \mathrm{C}$. The maximum removal percentage via this second stage $(9 \%)$ occurs with a combination of the highest temperature of $90{ }^{\circ} \mathrm{C}$ and the central applied pressure of $1650 \mathrm{kPa}$

(ii) For bentonite sludge, it is clear that by increasing the tem perature, the extent of thermal compression increases dra matically. For a low applied pressure of $300 \mathrm{kPa}$ (first stage) the percentage of water removal is only around $11 \%$ thus the only way to remove significant amounts of water is via thermal dewatering. At $55.5^{\circ} \mathrm{C}$ and $90^{\circ} \mathrm{C}$, the percent age of water removed via thermal compression (stage 2) exceeds $49 \%$ and $60 \%$, respectively, so it is by far the domi nant dewatering mechanism.

\subsection{Adequacy test of the model}

According to the statistical method, a second order polynomial function was assumed to approximate the final dry solids content. The adequacy test of the models, estimated by the determination coefficients, $R^{2}$, given in Table 2, revealed that they are quite ade quate with a value always greater than $80 \%$. It indicates that the regression model can predict the TAMD well, meaning that the model could explain greater than $80 \%$ of the variation in the pres sure and temperature.

\subsection{Optimization step}

In order to optimize the TAMD variables for the dry solids con tent response $Y$, the RSM was used. Using the analysis options dia log box (STATGRAPHICS ${ }^{\circledR}$ software) of the RSM, the range of each factor allowing the optimum dry solids content to be obtained is determined. After generating the polynomial equations relating the dependent and independent variables, the process was opti mized for the response $Y$. Optimization was performed to obtain the levels of $X_{1} X_{2}$ which maximize $Y$. The "optimum" points (tem perature $\left({ }^{\circ} \mathrm{C}\right)$, pressure $\left.(\mathrm{kPa})\right)$ for dry solids content concerning the three used substances was 80.3, 2661; 90.2, 2993; and 90.2, 2480 in case of talc suspension, cellulose suspension and bentonite sludge, respectively. Corresponding dry solids content was 78,64 , and 87 , respectively.

The final condition would be considered optimum if the tem perature and the pressure were as low as possible while the final dry solids content value was as high as possible. Therefore, the cri teria applied for graphical optimization were as follows: (a) mini mum temperature, (b) minimum pressure and (c) maximum dry solids content. During the TAMD, the energy aspect is very impor tant as well. Therefore, taking into account the energy aspect, the best combination of process variables for response functions is to be found. The selected "optimum" conditions for the thermally as sisted mechanical dewatering of the suspensions of fine particles were determined.

To conclude this optimization, in order to limit the energetic cost of the process and to obtain a satisfying final dry solids con tent the following conditions: temperature $\left({ }^{\circ} \mathrm{C}\right)$ of and pressure $(\mathrm{kPa})$ were 60.5, 1916; 60.5, 2040; and 90.2, 2480 in case of talc suspension, cellulose suspension and bentonite sludge, respec tively. The corresponding dry solids content were 70,58 , and 87 , respectively.

\section{Conclusions}

The TAMD was used to effectively dewater a range of materials, which derive from completely different sources, under a variety of processing conditions ranging from 21 to $90{ }^{\circ} \mathrm{C}$ and from 300 to $3000 \mathrm{kPa}$. Importantly, it has been illustrated that the TAMD can be used to remove a significant proportion of the inherent water from talc, cellulose and bentonite. It is found that, as a generaliza tion, the TAMD can remove approximately $7095 \%$ of the inherent water under moderate processing conditions. The potential exists to adapt the technology to an even more diverse range of materials.

The results of detailed dry solids content for talc, cellulose and bentonite have been presented. It is shown that both increasing temperature and increasing pressure increase the dry solids content. 
Experimental design methodology has been used in order to determine the effects of processing temperature $\left(2190^{\circ} \mathrm{C}\right)$ and processing pressure (300 $3000 \mathrm{kPa})$ on the dry solids content. CCRD was used to determine the level of process variables in the experimental runs. Second order equations were used to fit the experimental data and the adequacy of the model was checked considering the multiple determination coefficient, $R^{2}$, and $F$ ratio. After establishing the adequacy of the model, it was used for deducing the effect of these variables on the response. By using the RSM, the optimal set of operating variables were obtained graphically, in order to achieve the desired treatment level for the dry solids content.

\section{Acknowledgments}

The authors would like to acknowledge Bernard AUDUC for kind technical assistance in the construction and development of the experimental set up. The authors also gratefully acknowledge the financial and support received for this research from the ADEME.

\section{References}

AFNOR X31-505, 1994. Méthode de Détermination du Volume Apparent et du Contenu en Eau des Mottes. In: Recueil de Normes Françaises, Qualité des Sols. Paris, France.

Artanto, Y., Chaffee, A.L., 2005. Dewatering low rank coals by mechanical thermal expression (MTE) and its influence on organic carbon and inorganic removal. Coal Prep. 26, 251-267.

Bergins, C., Berger, S., Strauss, K., 1998. Process technology for mechanical/thermal dewatering. Aufbereit-Tech. 39, 58-70.

Bergins, C., Berger, S., Strauss, K., 1999a. Mechanical/thermal dewatering - a perspective for an efficient solid/liquid separation. Ceram. Forum Int. 76, 8-12.

Bergins, C., Berger, S., Strauss, K., 1999b. Dewatering of fossil fuel and suspension of ultrafine particles by mechanical/thermal dewatering. Chem. Eng. Technol. 22, 923-927.

Bergins, C., 2003. Kinetics and mechanism during mechanical/thermal dewatering of lignite. Fuel 82, 355-364.

Bergins, C. 2004. Mechanical/thermal dewatering of lignite. Part 2. A rheological model for consolidation and creep process. Fuel 83, 267-276.

Bergins, C., Hulston, J., Strauss, K., Chaffee, A.L., 2007. Mechanical/thermal dewatering of lignite. Part 3. Physical properties and pore structure of MTE product coals. Fuel 86, 3-16.

Bouyoucos, G.J., 1921. A new classification of soil moisture. Soil Sci. 11, 33-48.

Box, G.E.P., Draper, N.R., 1987. Empirical Model Building and Response Surface. John Wiley and Sons, New York.

Clayton, S.A., Scholes, O.N., Hoadley, A.F.A., Wheeler, R.A., Mcintosh, M.J., Huynh, D.Q., 2006. Dewatering of biomaterials by mechanical thermal expression. Dry Technol. 24, 819-834.
Clayton, S.A., Wheeler, R.A., Hoadley, A.F.A., 2007. Pore destruction resulting from mechanical thermal expression. Dry Technol. 25, 533-546.

Cochran, W.G. Cox G.M., 1957. Some methods for the study of response surfaces. In: Experimental Designs, second ed. John Wiley and Sons, New York.

Couturier, S., 2002. Etude de la Déshydratation Mécanique Assistée Thermiquement. Thèse de Doctorat LEPT ENSAM. Université de Bordeaux 1 France.

David, C., Montagne, M., Arlabosse, P., 2002. Thermal dewatering of paper sludge. In: Proceeding of the International Conference on Emerging Solid/Liquid Separation Technologies, Compiègne, France, pp. 69-74.

Fernandez, A., Arlabosse, P., Descoins, N., 2005. Thermally assisted mechanical dewatering: state of the art and new developments. Chem. Eng. Trans. 7, 737742

Giovanni, M., 1983. Response surface methodology and product optimization. Food Technol. 37, 41-45.

Hastie, S.K., Tibshirani, R., Friedman, J.H., 2001. The Elements of Statistical LearningData Mining, Inference and Prediction. Springer, New York.

Khuri, A.I., Cornell, J.A., 1987. Response Surface, Designs and Analysis. Marcel Dekker, New York

La Heij, E.J., Kerkhof, P.J.A.M., Kopinga, K., Pel, L., 1996. Determining porosity profiles during filtration and expression of sewage sludge by NMR imaging. AIChE J. 42 953-959.

Mahmood, T., Zawadski, M., Banerjee, S., 1998. Pilot study of impulse dryingindustrial sludge. Environ. Sci. Technol. 32, 1813-1816.

Mihoubi, D., Vaxelaire, J., Zagrouba, F., Bellagi, A., 2003. Mechanical dewatering of suspension. Desalination 158, 259-265.

Peuker, U.A., Stahl, W., 2001. Steam pressure filtration mechanical thermal dewatering process. Dry Technol. 19, 807-847.

Reichmann, B., Tomas, J., 2001. Expression behaviour of fine particle suspensions and the consolidated cake strength. Powder Technol. 121, 182-189.

Robinson, J., Knocke, W.R., 1992. Use of dilatometric and drying techniques for assessing sludge dewatering characteristics. Water Environ Res. 64, $60-68$.

Saveyn, H., Meersseman, S., Thas, O., Van der meeren, P., 2005. Influence of polyelectrolyte characteristics on pressure-driven activated sludge dewatering. Colloid Surf. A 262, 40-51.

Smollen, M., 1990. Evaluation of municipal sludge drying and dewatering with respect to sludge volume reduction. Water Sci. Technol. 22 (12), $153-161$.

Strauss, K., 1998. Method and device for reducing the water content of watercontaining brown coal. European Patent EP784,660.

Tsang, K.R., Vesilind, P.A., 1990. Moisture distribution in sludge. Water Sci. Technol 22 (12), 135-142.

Vaxelaire, J., Olivier, J., 2006. Conditioning for municipal sludge dewatering. From filtration compression cell tests to belt press. Dry Technol. 24, 1225-1233.

Vesilind, P.A., 1979. Treatment and Disposal of Wastewater Sludge. Ann Arbor Science, Michigan.

Vesilind, P.A., Martel, C.J., 1990. Freezing of water in wastewater sludge. J. Environ. Eng.-ASCE 116, 854-862.

Vesilind, P.A., 1994. The role of water in sludge dewatering. Water Environ. Res. 66, 4-11.

Wakeman, R.J., Tarleton, E.S., 1998. Filtration: Equipment Selection Modeling and Process Simulation. Elsevier, Oxford. 